\title{
É A MODULARIDADE MASSIVA UM PROGRAMA DE PESQUISA EMPIRICAMENTE PROGRESSIVO?
}

Is massive modularity an empirically progressive research program?

¿Es la modularidad masiva un programa de investigación empíricamente progresivo?

César Fernando Meurer ${ }^{1}$ Universidade Federal de Uberlândia, Uberlândia, MG, Brasil.

\section{Resumo}

A modularidade massiva pode ser descrita como um programa de pesquisa nos termos da filosofia da ciência de Lakatos. Cumpre, para tanto, identificar o núcleo, mostrar evidências de que ele é assumido como infalsificável (heurística negativa) e examinar estratégias de articulação e sofisticação do cinto de proteção (heurística positiva). No presente trabalho, faço isso com o intuito de responder à pergunta lançada no título. Em atenção a três desenvolvimentos recentes, cujas predições encontraram corroboração empírica, sou levado a inferir que esse programa é, de fato, empiricamente progressivo.

Palavras-chave: Modularismo. Cognição. Psicologia evolucionária. Lakatos.

\footnotetext{
1 Doutor em Filosofia pela Universidade do Vale do Rio dos Sinos (2016). Postdoctoral Visiting Scholar junto ao Departamento de Filosofia da Università Degli Studi di Milano (20172018). Pós-doutorando (PNPD/Capes) junto ao Programa de Pós-Graduação em Filosofia da Universidade Federal de Uberlândia (UFU). ORCID: http://orcid.org/ooo0-0002-9504-0325. E-mail: cesarmeurer@gmail.com
} 


\begin{abstract}
Massive modularity can be described as a research program, in Lakatos' philosophy of science terminology. Therefore, it is necessary to identify the hard-core, to show evidence that it is assumed as non-falsifiable (negative heuristics) and to examine strategies of articulation and sophistication of the protective belt (positive heuristics). In the present work, I do this in order to answer the question posed in the title. Considering three recent developments, whose predictions have found empirical corroboration, I am led to infer that this program is, indeed, empirically progressive.
\end{abstract}

Keywords: Modularity. Cognition. Evolutionary psychology. Lakatos.

\title{
Resumen
}

La modularidad masiva puede describirse como un programa de investigación, en términos de la filosofía de la ciencia de Lakatos. Por lo tanto, es necesario identificar su núcleo, mostrar evidencia de que se asume como infalsable (heurística negativa) y examinar estrategias de articulación y sofisticación del cinturón protector (heurística positiva). En el presente trabajo, emprendo estas tareas para responder a la pregunta planteada por el título. A la luz de tres desarrollos recientes, cuyas predicciones han encontrado corroboración empírica, infiero que este programa es empíricamente progresivo.

Palabras clave: Modularismo. Cognición. Psicología evolutiva. Lakatos.

\section{Introdução}

Qual é a arquitetura da cognição humana? Na década de 1980, Fodor propôs uma arquitetura tripartite que conta com transdutores, módulos periféricos e sistemas centrais não modulares (FODOR, 1983). ${ }^{2}$ Sob o influxo dessa proposta surgiram, na década de 1990, as primeiras defesas articuladas da ideia de que a cognição humana é toda constituída por módulos (TOOBY; COSMIDES, 1992; COSMIDES; TOOBY, 1994; SPERBER, 1996; PINKER, 1997). Essa proposta, a modularidade massiva, nasceu no interior de uma escola de pensamento conhecida como "psicologia evolucionária". No curso dos últimos vinte anos, ela vem inspirando esforços científicos em diversas áreas.

2 Cain (2002) oferece uma descrição bidirecional desse arranjo, isto é, do mundo para o pensamento [input transducers $\rightarrow$ input systems $\rightarrow$ central systems] e do pensamento para o mundo [central systems $\rightarrow$ output systems $\rightarrow$ output transducers]. Fodor, ele mesmo, não detalhou a segunda parte. 
O presente trabalho almeja avaliar a plausibilidade desta tradição de pensamento. Em termos mais rigorosos: é a modularidade massiva um programa de pesquisa empiricamente progressivo, no sentido que Lakatos $(1970 ; 1971)$ conferiu a essa expressão?

Permita-me resgatar sucintamente o que são programas de pesquisa e o que os torna empiricamente progressivos. Segundo Lakatos (1970, p. 133 [1979, p. 163]), um programa de pesquisa é dotado de um núcleo - "a ideia diretora e 'irrefutável' que o caracteriza e move" (REGNER, 1994, p. 107) - e é desenvolvido através de uma heurística negativa e de uma heurística positiva.

\begin{abstract}
A heurística negativa especifica o "núcleo" do programa, que é "irrefutável" por decisão metodológica dos seus protagonistas; a heurística positiva consiste num conjunto parcialmente articulado de sugestões ou palpites sobre como mudar e desenvolver as variáveis refutáveis do programa de pesquisa e sobre como modificar e sofisticar o cinto de proteção "refutável" (LAKATOS, 1970, p. 135 [1979, p. 165]).
\end{abstract}

O núcleo do programa, irrefutável, é acompanhado por um conjunto de variáveis refutáveis, o cinto de proteção. Desenvolver o programa significa, em termos simples, trabalhar no aperfeiçoamento e expansão desse cinto, o que envolve articulação e rearticulação de hipóteses e teorias auxiliares (heurística positiva). O trabalho é conservador, por um lado, e criativo, por outro. $\mathrm{O}$ aspecto conservador, Lakatos deixa claro, diz respeito ao compromisso de preservar o núcleo, que não pode ser falseado e tampouco modificado (heurística negativa). $\mathrm{O}$ aspecto criativo diz respeito às estratégias de desenvolvimento e sofisticação do cinto de proteção.

Sob o prisma de Lakatos (1970 [1979]; 1971), programas de pesquisa resultam ser progressivos ou degenerativos. “[...] um programa de pesquisa está progredindo enquanto o seu crescimento teórico antecipa seu crescimento empírico, isto é, enquanto ele mantém previsão de fatos novos com algum 
sucesso" (LAKATOS, 1971, p. 104, grifo do autor, tradução nossa)3. Com outras palavras, o cinto de proteção de um programa progressivo encontra-se em expansão: há um crescimento no volume de conteúdo, por assim dizer. Essa expansão há de ocasionar predições novas ${ }^{4}$ e, se alguma delas é corroborada empiricamente, então temos um programa empiricamente progressivo.

Nem todos os programas possuem um cinto de proteção em expansão. Em alguns, ele pode estar estagnando. Para Lakatos, "um programa está estagnando quando o crescimento teórico ocorre depois do crescimento empírico, isto é, o programa só produz explicações post-hoc" (LAKATOS, 1971, p. 105, grifo do autor, tradução nossa). Eventualmente, o cinto de proteção entra em processo de degeneração (um decréscimo no volume de conteúdo; um espécie de "encolhimento"). A articulação de exceções e de hipóteses ad hoc são indicadores dessa degeneração. O ponto é: quando o cinto de proteção está estagnado ou degenerando, ele falha em produzir fatos novos.

Está claro, então, que o caráter progressivo de um programa não decorre do núcleo enquanto tal, mas da performance do cinto de proteção. Performance, nesse caso, designa a capacidade de vincular o núcleo com dados empíricos. É, pois, em atenção à heurística positiva (a dimensão criativa) que se pode aferir a progressividade de um programa.

Entendo que a filosofia da ciência de Lakatos oferece tanto o enquadramento (teorias como programas) quanto as ferramentas apropriadas (é a teoria progressiva ou não) para avaliação de teorias psicológicas. Esse entendimento encontra amparo em Newell (1990), que considera que o status científico da psicologia é melhor apreciado sob esse prisma 5 . Com efeito, o falseacionismo

\footnotetext{
3 A tradução desta e de todas as demais citações diretas é minha (tradução livre).

4 Conta como predição a antecipação de uma ocorrência ou estado de coisas observável (FORSTER, 2014, p. 449).

5 Newell está pensando nos critérios que distinguem ciência de pseudociência. Se aplicarmos os critérios propostos por Popper, ele diz, então a psicologia não passa no teste. Cumpre, pois, defender a cientificidade dela sob o prisma de Lakatos. "Nós não estamos vivendo no mundo de Popper... até onde eu sei, nós estamos vivendo no mundo de Lakatos" (NEWELL, 1990, p. 14, tradução nossa). Bjorklund (1997) suspeita que a psicologia não possui um núcleo coerente "um conjunto amplo, abrangente e compartilhado de princípios e suposições para orientar suas
} 
sofisticado supera a visão ingênua segundo a qual uma teoria pode ser "derrubada com um único tiro". Teorias não são verdadeiras ou falsas, como essa visão ingênua parece sugerir, mas aproximadas. É justamente esse caráter aproximado que oportuniza melhorias, ajustes, ampliações, reformulações e correções diversas. Daía ideia de um programa desenvolvido heuristicamente ${ }^{6}$.

Em face dessas considerações, a interrogação que dá título ao artigo pode ser desmembrada em três: (1) Qual é o núcleo desse programa de pesquisa chamado "modularidade massiva"?; (2) Quais são os elementos que ajudam a compreender a heurística negativa?; e (3) O que os pesquisadores vinculados a esse programa têm produzido com vistas ao desenvolvimento e à sofisticação do cinto de proteção? No que segue, tomo essas questões como fio condutor e trato de elaborar respostas para elas. Quanto à (1), procurarei mostrar que a noção de módulo, esse compreendido como mecanismo que evoluiu para processar informações de um domínio específico, é a ideia nuclear. Acerca de (2), mostro que os pesquisadores desse programa elaboraram um conjunto de argumentos destinados a "blindar" o núcleo ["blindar" no sentido de proteger ao máximo; resguardar]. Chamarei isso de "heurística negativa em forma de argumentos". Considero que isso está em sintonia com a visão de Lakatos, para quem a heurística negativa especifica o núcleo e realça que ele é assumido como infalsificável. Por fim, em (3), concentro-me em três desenvolvimentos recentes no cinto de proteção. A análise é feita de modo a realçar a sintonia com o núcleo, as predições e a subsequente corroboração empírica. Com base nessas evidências, devo concluir que a modularidade massiva é, de fato, um programa empiricamente progressivo.

pesquisas" (BJORKLUND, 1997, p. 144, tradução nossa) -, o que constitui um impedimento de grande magnitude para o seu desenvolvimento como ciência.

6 Estou aqui ecoando algumas críticas que Putnam dirige a Popper em um texto dado à estampa em 1974. Embora Putnam não mencione a obra de Lakatos, a sintonia de ideias é evidente: “(1) teorias não implicam predições; apenas a conjunção de uma teoria com certas 'declarações auxiliares' [auxiliary statements - A. S.] que, em geral, implica uma predição. (2) As declarações auxiliares [A. S.] são frequentemente suposições sobre condições de fronteira [...] altamente arriscadas enquanto tais. (3) Visto que temos pouca certeza da A. S., não podemos considerar uma predição falsa como definitivamente falsificando uma teoria; teorias não são plenamente falsificáveis" (PUTNAM, 1974, p. 229, tradução nossa). 


\section{Em busca do núcleo do programa}

Symons (1995) aponta que a psicologia evolucionária tem raízes no assim chamado Programa Adaptacionista na Biologia (The Adaptationist Program in Biology). Resumidamente, tal programa objetiva "reconhecer certas características do organismo como componentes de certa maquinaria especial de solução de problemas. Tais mecanismos de solução de problemas são chamados 'adaptações'” (SYMONS, 1995, p. 81, tradução nossa)7.

Nos anos 1980, ganhou força a ideia de que esse programa pode ser transposto ao estudo do comportamento humano. O raciocínio que encoraja essa transposição é aproximadamente este: (i) Qualquer teoria minimamente consistente do comportamento humano assume, ainda que implicitamente, a existência de algum mecanismo psicológico típico da espécie; (ii) A evolução por seleção natural é a melhor explicação científica da origem e manutenção de tal(is) mecanismo(s) ${ }^{8}$; e (iii) A pesquisa psicológica que se concentra nos mecanismos para a solução de problemas recorrentes (ao longo de gerações) merece, por conta disso, o adjetivo "evolucionária".

Sob o prisma em comento, tais problemas recorrentes são fundamentalmente problemas de processamento de informação. Considere, por exemplo, nossos ancestrais caçadores-coletores. É razoável afirmar que, ao longo de incontáveis gerações, eles enfrentaram problemas de diversos tipos: selecionar comida, escolher parceiro/a sexual, negociar hierarquia

\footnotetext{
7 Symons (1995, p. 81-86) oferece uma descrição da natureza e do escopo desse programa.

8 As outras opções são: criacionismo (a ideia de que uma divindade criou e organizou tudo) e a teoria da semeadura (a ideia de que a vida não se originou no planeta terra, mas chegou aqui trazida por um meteoro ou por seres extraterrestres). O criacionismo não tem status de teoria científica, pois (a) não pode ser testado empiricamente; (b) não fornece orientações para futuras pesquisas; e (c) não possui força explanatória (Cf. KENNAIR, 2003). A teoria da semeadura pode, em princípio, ser testada (ex.: estudar meteoros em busca de sinais de vida; estudar a superfície da terra em busca de marcas deixadas por extraterrestres, estudar o universo e assim por diante). No entanto, (a) faltam evidências que corroboram a chegada, por assim dizer, da vida à terra; (b) a teoria não leva a novas descobertas; e (c) a teoria incorre no assim chamado problema do regresso, já que simplesmente "empurra para trás" a explanação causal da origem da vida (Cf. BUSS, 2008). A teoria da evolução por seleção natural é cientificamente melhor pois (a) oferece uma estrutura que organiza o que se conhece hoje sobre o mundo natural; (b) fornece orientações para investigações futuras; e (c) cria condições para novas predições.
} 
social, selecionar habitats e assim por diante. Presumivelmente, cada um desses problemas exigia uma solução específica, distinta das demais. É improvável que a escolha de comida (leia-se: os processos de identificar, selecionar, ingerir e armazenar) siga a mesma lógica, por assim dizer, da escolha de parceiro/a sexual. Logo, é improvável que o mecanismo associado à escolha de comida seja similar (tanto nos inputs relevantes quanto no cômputo e nos outputs) ao mecanismo associado à escolha de parceiro/a sexual. Faz sentido, pois, postular que a psique humana evoluiu distintos mecanismos especializados (/de domínio específico). Nas palavras de Symons (1995, p. 86, tradução nossa) “não há solucionador geral de problemas, pois não há problema geral". Acreditar na existência de um mecanismo solucionador geral de problemas no âmbito psicológico - Symons provoca - faz tanto sentido quanto acreditar na existência de um órgão solucionador geral de problemas no âmbito fisiológico.

Quais são os problemas específicos de processamento de informação que os nossos ancestrais enfrentaram ao longo da deriva evolutiva? Quais são as adaptações (/mecanismos ${ }^{9}$ ) que possivelmente evoluíram como soluções desses problemas? Ao meu modo de interpretar, essas duas perguntas são centrais na pauta da psicologia evolucionária. Considere o que dizem Cosmides, Tooby e Barkow (1992, p. 3, tradução nossa): "psicologia evolucionária é simplesmente psicologia informada pelo conhecimento adicional que a biologia evolucionária tem a oferecer, na expectativa de

\footnotetext{
9 Entende-se que o processo evolucionário ocasiona três produtos: adaptações, subprodutos (by-products) e efeitos aleatórios. Em poucas palavras, uma adaptação pode ser descrita como algo herdado, que surgiu por seleção natural pois ajudou a solucionar um problema de importância vital durante certo período evolutivo. Em decorrência disso, uma adaptação se desenvolve de modo estável em todos os membros da espécie. Elementos temporários, ou que são facilmente alterados pelo ambiente, ou que aparecem apenas em alguns membros da espécie, não são adaptações. Assim, no âmbito da psicologia do processamento de informações, é apropriado dizer que uma adaptação é um mecanismo. Tooby e Cosmides (1990) entendem que "adaptações são o resultado de certa coordenação, desencadeada pela seleção como um processo de feedback. Elas são reconhecíveis pelo design especial - isto é, por uma coordenação não aleatória entre propriedades do fenótipo e ambiente". Essa coordenação não aleatória, eles prosseguem, pode ser vista como uma espécie de entrosamento "para promover o fitness" (TOOBY; COSMIDES, 1990, p. 25, tradução nossa).
} 
que o entendimento dos processos que moldaram a mente humana vai avançar a descoberta de sua arquitetura". As pesquisas desse campo, eles prosseguem, "focam os mecanismos de processamento de informação da mente humana, [...]. Esses mecanismos são os produtos elaboradamente esculpidos do processo evolucionário".

Symons (1995) acerta ao dizer que a psicologia evolucionária tem raízes na biologia. No entanto, cabe gizar também as raízes que estão no computacionalismo. Nesse sentido, Pinker (1997) considera que a psicologia evolucionária surge do encontro de duas revoluções científicas: a revolução cognitiva, "que explica os mecanismos do pensamento e das emoções em termos de informação e computação", e a revolução na biologia evolucionária, "que explica o design adaptativo complexo de seres vivos em termos de seleção entre replicadores" (PINKER, 1997, p. 23, tradução nossa). Penso que Pinker foi bem-sucedido em iluminar os dois lados da moeda: o lado cognitivo, descrito em termos de informação e computação, e o lado evolucionário, descrito em termos de pressões seletivas e adaptações.

Digamos que o termo "módulo"' abrevia "mecanismo de processamento de informação esculpido evolucionariamente". Pinker avaliza isso quando escreve que "a mente é organizada em módulos ou órgãos mentais", cada um deles "moldado por seleção natural para resolver os tipos de problemas que os nossos ancestrais enfrentaram" (PINKER, 1997, p. 21, tradução nossa).

Sperber (1996, p. 120, tradução nossa) acentua o lado cognitivo (/computacional) dos módulos da mente: "Um módulo cognitivo é um dispositivo computacional da mente/cérebro". Tal dispositivo, ele explica, opera de modo relativamente autônomo a partir de inputs oriundos de receptores sensoriais ou de outros módulos. Esse "ou" é, evidentemente, uma disjunção inclusiva.

O que levou essa tradição a crer que a cognição é massivamente modular? Resposta direta: a inviabilidade computacional de uma arquitetura cognitiva não modular. Cosmides e Tooby (1994) ajuízam que a evolução tende a favorecer módulos especializados de domínio específico em detrimento de mecanismos de domínio geral, pois (i) módulos especializados são uma solução de engenharia superior em termos de confiança, celeridade e eficiência (o 
problema da solução de engenharia); (ii) módulos especializados acumularam, ao longo do tempo evolutivo, critérios de acerto-erro específicos do seu domínio (o problema do acerto-erro); (iii) módulos especializados encontram-se equipados com informações do seu domínio, buriladas ao longo de muitas gerações, o que permite que sigam operando quando as informações do ambiente externo são insuficientes ou difusas (o problema da pobreza de estímulo); e, finalmente, (iv) uma arquitetura cognitiva massivamente modular lida melhor com casos complexos, nos quais as possibilidades se multiplicam exponencialmente (o problema da explosão de possibilidades) ${ }^{10}$.

O exposto é suficiente para retomar a questão que motivou a presente seção: (1) Qual é o núcleo do programa de pesquisa "modularidade massiva"? Resposta: a ideia de que a cognição humana é toda formada por módulos, esses entendidos como mecanismos especializados de processamento de informação, moldados por seleção natural. Isso significa que são modulares não apenas as periferias, como pensa Fodor, mas "também as regiões centrais, responsáveis pelo raciocínio e pela tomada de decisões" (SAMUELS, 2006, p. 37, tradução nossa).

Eraña (2012, p. 857, tradução nossa) formulou elegantemente a ideia-chave (o núcleo) da modularidade massiva: "A mente humana é um dispositivo de processamento de informação composto por módulos, isto é, sistemas especializados que podem ser descritos em termos computacionais e que foram moldados por seleção natural para executar funções específicas".

Sob o prisma de Lakatos (1970 [1979]), vimos na introdução, o núcleo de um programa de pesquisa é considerado irrefutável por decisão metodológica dos pesquisadores. No entanto, um programa não se resume ao núcleo. Há uma heurística negativa e uma heurística positiva (um trabalho conservador e um trabalho criativo, para recuperar os termos usados na introdução). Esses são os assuntos das próximas seções.

10 Para uma apresentação mais detalhada desses argumentos, cf. Meurer (2017). 


\section{A "blindagem" do núcleo: argumentos evolucionistas e computacionais}

Vimos, na seção anterior, que o núcleo do programa da modularidade massiva conta com um componente evolucionista (os módulos foram moldados por seleção natural) e com um componente computacional (o processamento de informação pode ser descrito em termos computacionais). No núcleo, como tal, não há argumentação. O que há são ideias-chave, tidas como irrefutáveis, que caracterizam o programa e movem os pesquisadores.

Em torno do núcleo, defensores da modularidade massiva elaboraram um conjunto de argumentos de teor evolucionista que se combinam com argumentos de teor computacional. Interpreto esse esforço argumentativo como um trabalho de "blindagem" do núcleo do programa. Uso "blindar" no sentido de resguardar; proteger ao máximo; tornar resistente. Com efeito, esse desenvolvimento argumentativo não visa a produção de "fatos novos". É uma heurística negativa em forma de argumentos, por assim dizer. Ou, se você preferir, um trabalho conservador, que especifica o núcleo e destaca que ele é tido como infalsificável.

No que segue, tomo o influente The Architecture of Mind (CARRUTHERS, 2006) como referência principal para apresentar três proeminentes argumentos de "blindagem": (3.1) o argumento do design, (3.2) o argumento dos animais e (3.3) o argumento da tratabilidade computacional. Além de esquematizar os argumentos, mostro também que eles guardam sintonia com entendimentos aceitos em outras áreas.

\section{1 $O$ argumento do design}

O argumento do design é um argumento de teor evolucionista que pode ser esquematizado tanto em versão dedutiva quanto em versão indutiva. No primeiro caso, o percurso segue assim: (1) Diante de problemas adaptativos, sistemas biológicos evoluem em direção a soluções otimizadas; (2) O design modular é uma solução otimizada, tanto para o todo quanto para as partes do sistema; (3) A cognição é uma parte de um sistema biológico; logo, (4) 
A cognição é organizada por módulos. Na versão indutiva do mesmo argumento, o ponto de partida tem a forma de uma generalização empírica: (1) Virtualmente, todos os sistemas biológicos complexos possuem design modular; (2) A cognição é um sistema complexo; logo (3) A cognição é organizada por módulos (CARRUTHERS, 2006, p. 12-28).

Considero que esse argumento foi concebido para "blindar" o núcleo do programa, no sentido mencionado acima. De fato, Carruthers espera que essa linha de raciocínio evidencie que a cognição humana se encontra "estruturada por sistemas que são em certa medida dissociáveis, cada qual com uma função distinta a executar" (CARRUTHERS, 2006, p. 17, tradução nossa).

Diante desse raciocínio, é provável que o leitor se pergunte: o que pesquisadores da grande área das Ciências Biológicas estão dizendo acerca do design modular? De acordo com Barrett (2007, p. 163, tradução nossa) "quando um biólogo olha para seres vivos, ele vê modularidade em toda parte". Efetivamente, pesquisadores da grande área das Ciências Biológicas já identificaram inúmeras estruturas e processos modulares no mundo natural: proteínas" e genes ${ }^{12}$ (LITVIN et al., 2009), células (HARTWELL et al., 1999; WAGNER, 1996), órgãos (SCHLOSSER; WAGNER, 2004), ecossistemas (KRAUSE et al., 2003; MONTOYA; PIMM; SOLÉ, 2006), redes metabólicas e cadeias alimentares (SPIRIN et al., 2008). Finalmente, também o corpo de um animal pode ser decomposto em unidades fun-

\footnotetext{
1 Encontramos, na literatura, estudos interessantíssimos de conectividade física de proteínas. Em uma pesquisa focada em leveduras, Han et al. (2004) distinguiram dois tipos distintos de hubs de interação proteína-proteína: aqueles cuja conectividade é densa tanto no espaço quanto no tempo (chamados de party hubs em analogia ao que acontece em uma festa, a dizer, muitas conexões ao mesmo tempo e no mesmo espaço) e aqueles hubs cuja conectividade é distribuída no espaço e no tempo (esses receberam o sugestivo nome date hubs). Fraser (2005) mostrou que mutações nos party hubs são altamente restritas - isto é, são como que contidas dentro do módulo - enquanto mutações nos date hubs se disseminam sem maiores restrições.

12 Gostaria de mencionar, a título de exemplo, o mapeamento lógico de redes reguladoras de genes de Thieffry e Sanchez (2004). Baseados em noções simples como "true" para "o gene está ativo" e "and" e "or" para as interações, eles conseguiram decompor complexas redes reguladoras em conjuntos de circuitos interligados. Ao comentar seus resultados, os autores registram: "nós conseguimos derivar um método simples e racional para a decomposição de redes genômicas complexas em módulos dinâmicos, bem-definidos e relativamente autônomos" (THIEFFRY; SANCHEZ, 2004, p. 238,, tradução nossa, grifo nosso).
} 
cionais relativamente independentes (KLINGENBERG, 2008; HE; DEEM, 2010). Com a corroboração da ciência, é razoável afirmar que todos os sistemas biológicos complexos do nosso tempo possuem design modular.

Outra noção-chave do argumento do design é a própria noção de evolução. A ideia geral, de que os sistemas biológicos complexos do presente foram de alguma maneira moldados pela evolução, ganhou ao longo da ciência moderna uma vasta corroboração. O ponto principal, assim se pensa, é que tal design obteve vantagens importantes no processo evolutivo. Lorenz, Jeng e Deen (2011, p. 5) sumarizam: sistemas biológicos modulares são mais robustos, pois perturbações e falhas em um módulo não afetam o todo, e melhoram a evolutividade (evolvability), pois esse design favorece tanto a otimização por partes quanto as adaptações funcionais. Com efeito, robustez, evolutividade e adaptação funcional são as vantagens do design modular mencionadas com mais frequência na literatura biológica.

Autoridade em robustez biológica, Hiroaki Kitano explica que esse termo designa a propriedade "que permite ao sistema manter suas funções apesar de perturbações externas e internas" (KITANO, 2004, p. 826, tradução nossa). Gize-se: manter as funções é distinto de manter estabilidade (KITANO, 2007³). Quanto à evolutividade (evolvability), existe na biologia evolucionária do nosso tempo uma tensão relativa ao significado dessa expressão. Brown (2014), por exemplo, constata que "permanece um desacordo considerável acerca do que é evolutividade" (BROWN, 2014, p. 549, tradução nossa). A autora propõe que esse termo seja reservado para designar "uma propriedade disposicional, robusta e abstrata [...] que capta a influência causal conjunta das características internas [do sistema] sobre os resultados da sua evolução (em oposição à influência causal da seleção, que é frequentemente caracterizada como externa)" (BROWN, 2014, p. 549, tradução nossa). Finalmente, a expressão "adaptação funcional" é comumente usada para designar ajuste no funcionamento do sistema. $\mathrm{O}$

13 Além de distinguir criteriosamente "funcionalidade" de "estabilidade", Kitano (2007) apresenta uma formulação matemática para a sua teoria da robustez. 
exemplo clássico é o do coração durante uma corrida, circunstância na qual as células dos músculos queimam mais glicose, o que requer mais oxigênio. Sendo esse trazido pelo sangue, o coração acelera para suprir a demanda.

$\mathrm{O}$ argumento do design é cientificamente bem informado. Quer isso significar que o núcleo do programa guarda sintonia com entendimentos estabelecidos em outras áreas do conhecimento. Isso, no entanto, não responde à pergunta que dá título ao presente trabalho. Como mencionei na abertura da seção, entendo que o argumento do design é melhor interpretado como um argumento que tem a função de especificar e resguardar o núcleo do programa. Não é heurística positiva.

\subsection{O argumento dos animais}

O assim chamado 'argumento dos animais' combina um aspecto evolucionista com um aspecto computacional. Ele pode ser esquematizado assim: (1) A cognição de animais não-humanos que possuem sistema nervoso central tem arquitetura massivamente modular; (2) A evolução biológica tende a preservar e modificar estruturas existentes ao invés de iniciar novas; logo, (3) A cognição humana também possui arquitetura massivamente modular (CARRUTHERS, 2006, p. 29-35; p. 65-149).

A questão-chave desse argumento é a primeira premissa. De acordo com Carruthers (2006, p. 149), ela deve ser lida como uma inferência à melhor explicação dos comportamentos observáveis.

Os animais exibem uma grande variedade de habilidades para aprender e para adaptar desejos [às circunstâncias]. Não é sequer remotamente plausível que todas essas habilidades sejam suportadas por um dispositivo geral de condicionamento associativo. (Ademais, o fato de alguns animais se destacarem em apenas algumas dessas tarefas, enquanto outros não, conta diretamente contra tal sugestão.) De fato, as evidências sugerem que inclusive os comportamentos condicionados são melhor explicados como resultantes das 
operações de um módulo especializado em estimativas operando com diferentes objetivos e esquemas de ação. E, visto que as demandas computacionais de tarefas de aprendizagem ou aquisição de habilidades são muito diferentes de um caso para outro, é altamente plausível que haja diferentes dispositivos especializados para diferentes tarefas (CARRUTHERS, 2006, p. 149, tradução nossa).

Em áreas como a zoologia e a psicologia experimental, tem-se como empiricamente estabelecido que animais (leia-se: animais não-humanos que possuem sistema nervoso central) têm capacidade de aprender e resolver problemas de considerável complexidade. Para dissipar a aparente trivialidade dessa afirmação é oportuno perguntar: O que é essa capacidade de aprender? Segundo Gallistel (2000, p. 1179), a melhor resposta é aquela que menciona mecanismos de aprendizagem, estes entendidos como mecanismos especializados para resolver tipos específicos de problemas. A ideia é a seguinte: assim como há distintos tipos de problemas, há distintos mecanismos de aprendizagem. "Mecanismos de aprendizagem, tal como outros mecanismos biológicos, invariavelmente exibem especialização", diz Gallistel. Segundo esse autor, a existência de um mecanismo de aprendizagem de propósito geral faz tanto sentido quanto a existência de um órgão sensorial de propósito geral (GALLISTEL, 2000, p. 1190, tradução nossa).

A ideia de especialização fica mais clara se considerarmos que vários mecanismos de aprendizagem identificados em animais incluem cômputos: o animal precisa ser capaz de selecionar e processar informações relevantes em meio a uma infinidade de dados disponíveis.

Todos os animais precisam enfrentar os problemas colocados por ambientes variáveis, tais como encontrar e processar comi$\mathrm{da}$, reconhecer e atrair potenciais parceiros, evitar predadores, superar rivais e retornar ao ninho. Embora sejam variados os processos mentais pelos quais diferentes espécies lidam com 
tais desafios, todos compartilham o problema fundamental de ter que lidar com a abundância de informações no ambiente, muitas das quais provavelmente não relevantes para a tarefa em questão. O primeiro passo, portanto, é tentar peneirar a massa de dados e atentar àquilo que pode informar a tomada de decisão. Tendo adquirido os dados relevantes, o animal pode estabelecer como as diferentes informações se relacionam entre si. Indicam as flores amarelas de forma confiável a presença de néctar? Um sinal de um macho dominante é sinal de perigo eminente? Em ambientes complexos, pode ser vantajoso não só ter em conta a co-ocorrência estatística de estímulos diferentes, mas também extrair regras gerais, permitindo agir de forma flexível e resolver uma grande variedade de problemas em diferentes contextos (THORNTON; CLAYTON; GRODZINSKI, 2012, p. 2670, tradução nossa).

Esse fragmento é representativo de uma visão amplamente difundida entre pesquisadores que se dedicam a avançar no conhecimento da cognição de animais não humanos. Tais animais, assim se entende, são capazes de perceber o entorno, perceber o próprio corpo, selecionar e processar informações, planejar e executar ações. De acordo com o argumento de Carruthers, a melhor explicação para isso é aquela que postula a existência de módulos especializados.

A cognição de animais não humanos é, provavelmente, do tipo goal-directed. Hills (2006) considera que o papel da dopamina no nível celular é central para compreender a evolução da "goal-directed cognition". Amparado por uma longa lista de estudos desse neurotransmissor, ele propõe que a "maquinaria que inicialmente evoluiu para controle de comportamento e de forrageamento foi, ao longo do tempo evolutivo, cooptada para modular o controle da goal-directed cognition" (HILLS, 2006, p. 4, tradução nossa).

Esses comentários sobre o argumento dos animais são bastante gerais. Note, por exemplo, que empreguei genericamente a expressão "processar informações". De fato, falar em processos cognitivos é, em boa medida, uma 
questão de falar de processamento de informação. Se um animal é capaz de selecionar e processar dados relevantes para determinada circunstância (proteção, alimentação, reprodução etc.), então faz sentido dizer que de alguma maneira ele é capaz de representar internamente esses dados. Assim, falar em processos cognitivos implica examinar a natureza dessa entidade que é frequentemente chamada "representação". Esse exame, por sua vez, também proporciona esclarecimento da noção de "informação".14

Ao meu modo de pensar, o argumento dos animais cumpre função similar à do argumento do design: especificar e blindar o núcleo. Se a minha interpretação estiver correta, esse argumento é conservador e não visa a produção de fatos novos. Uma heurística negativa em forma de argumentação.

\subsection{O argumento da tratabilidade computacional}

O argumento da tratabilidade computacional é, como o próprio nome indica, um argumento de teor computacional. Também ele foi concebido com o intuito de "blindar" o núcleo do programa de pesquisa aqui em discussão. Eis a esquematização: (1) A cognição humana se realiza mediante processos computacionais; (2) Todos os processos computacionais mentais precisam ser viáveis; (3) Apenas processos que são, em certa medida, informacionalmente encapsulados são computacionalmente viáveis; logo, (4) A cognição humana é inteiramente constituída por sistemas que são, em certa medida, informacionalmente encapsulados (CARRUTHERS, 2006, p. 44-45).

Cumpre sinalizar que esse argumento espelha um conjunto de argumentos forjados nos anos 1990 (COSMIDES; TOOBY, 1994), época dos principais embates com a escola fodoriana (MEURER, 2017). O ponto tenso daqueles embates é a noção de encapsulamento informacional.

\footnotetext{
14 As noções de "representação", "informação" e "processamento" são centrais não apenas no âmbito dos estudos da cognição de animais não humanos. Essas noções moldam profundamente toda e qualquer investigação cognitiva. Com outras palavras: quando vinculamos e determinamos essas noções, torna-se claro o rumo teórico da pesquisa.
} 
Para a escola fodoriana, "a chave da modularidade é o encapsulamento informacional" (FODOR, 1983, p. 98; FODOR, 2000, p. 56, tradução nossa). Apostando em uma noção estrita de módulo - este é necessariamente um mecanismo informacionalmente encapsulado - Fodor termina convencido de que apenas os Input Systems são modulares e podem ser modelados computacionalmente. Sob esse prisma, há um sistema central que dificilmente é modular. Defensores da modularidade massiva aceitam de bom grado que alguns módulos sejam informacionalmente encapsulados. No entanto, outros não são. O encapsulamento informacional é uma questão de grau, e essa ideia viabiliza a hipótese de mecanismos de domínio específico também nas regiões mais centrais da cognição.

A distinção encapsulamento estrito versus encapsulamento lato vem a calhar. Sob o prisma de Fodor (1983), o encapsulamento informacional é entendido em sentido estrito: diz-se que certo sistema é encapsulado se o processo não pode ser afetado por outras informações. Contra Fodor, a tradição da modularidade massiva insiste em que há módulos que são encapsulados em sentido lato: eles recebem inputs de outros módulos. Nas palavras de Carruthers, "um módulo pode ser um sistema que precisa considerar apenas um pequeno sub-conjunto de toda a informação disponível" (2006, p. 58-59, tradução nossa, grifo no original).

Em publicação posterior, Carruthers (2008) enfatiza a importância de redimensionar a noção de encapsulamento: “Para quem almeja defender a tese da modularidade massiva, o desafio é responder aos argumentos fodorianos contra a modularidade dos sistemas centrais enfraquecendo a noção fodoriana de 'módulo' o mínimo possível" (CARRUTHERS, 2008, p. 293, tradução nossa). Gize-se: enfraquecer a noção de módulo não significa rejeitar a ideia de encapsulamento. Significa, sim, apostar na possibilidade de módulos que recebem inputs uns com os outros.

Ora, uma coisa é dizer que certo módulo recebe inputs de outros módulos. Coisa diferente é dizer que o cômputo que esse mecanismo executa é acessível a outros módulos. O ponto é: um módulo pode receber inputs de outros módulos e, ainda assim, executar um cômputo 
(operação interna) que é inacessível a tais outros módulos. Uma das formulações mais claras desse ponto está no início do The Architecture of Mind (CARRUTHERS, 2006), onde se lê que

[...] sistemas modulares devem ser frugais no uso de informações e outros recursos cognitivos, e ter operações internas que são amplamente inacessiveis aos outros sistemas. A tese da modularidade massiva é então a afirmação de que a mente é composta de muitos sistemas de processamento funcionalmente isoláveis que possuem tais propriedades e que possuem múltiplas conexões de entrada e saída com outros tais sistemas (CARRUTHERS, 2006, p. xii, tradução nossa, grifo no original).

Essa passagem esclarece o argumento da tratabilidade computacional. Definitivamente, o conceito de "módulo" desse programa de pesquisa é distinto do conceito fodoriano de módulo. A ideia de que um módulo possui acesso frugal à informação faz sentido, tanto pelo viés evolutivo quanto pelo viés computacional. Em suma, a questão da viabilidade computacional de certo módulo é uma questão de moderação com respeito tanto aos inputs quanto à complexidade algorítmica das operações internas.

Para concluir a seção: interpreto que o argumento da tratabilidade computacional é um argumento conservador. Ele foi concebido com a intenção de especificar e resguardar o núcleo do programa. Resguardar, nesse caso, significa demonstrar que a ideia-nuclear é computacionalmente viável. Com outras palavras, a modularidade massiva está assentada em uma ideia que funciona no nível computacional e algorítmico.

Na próxima seção, avanço para a questão (3), já anunciada na introdução: o que os pesquisadores vinculados a esse programa têm produzido com vistas ao desenvolvimento e sofisticação do cinto de proteção? Explorarei alguns desenvolvimentos recentes que indicam que esse programa é, de fato, empiricamente progressivo. 


\section{A dimensão criativa do programa: vincular o núcleo com dados empíricos}

Um programa de pesquisa possui uma dimensão criativa, que inclui a produção de hipóteses e modelos passíveis de avaliação empírica (LAKATOS, 1970 [1979]). Nesse plano, vimos na introdução, trata-se de vincular o núcleo a dados empíricos. Quando essa vinculação se mostra bem-sucedida, o programa ganha status de "progressivo".

Para a modularidade massiva, módulos são adaptações que evoluíram para a solução de problemas de processamento de informações. Logo, a heurística positiva inclui o trabalho de identificar e descrever tais adaptações. Se esse trabalho gera fatos novos, então o programa é empiricamente progressivo.

Para o presente propósito - aferir se a modularidade massiva é um programa empiricamente progressivo -, é suficiente apresentar alguns aspectos do cinto de proteção. No que segue, exploro três hipóteses de adaptações que têm sido objeto de discussão na comunidade científica. Vou fazê-lo de modo a evidenciar a sintonia com o núcleo, as predições e a corroboração empírica.

\subsection{Atração sexual e reprodução}

A psicologia da atração sexual e da reprodução humana é de capital importância para o programa de pesquisa aqui em comento. A hipótese-chave nesse domínio é mais ou menos esta: achar alguém bonito/a, sentir-se atraído/a, apaixonar-se, sentir ciúmes... são ocorrências suportadas e reguladas por uma complexa maquinaria computacional especializada.

Consideremos a questão da escolha de parceiro/a sexual. Buss (1992) ajuíza que mulheres e homens enfrentaram, ao longo do tempo evolucionário, diferentes pressões relativas a essa escolha. Faz sentido, portanto, postular que "pressões seletivas ao longo do tempo evolucionário deram origem a mecanismos; nesse caso, mecanismos de preferência [sexual]" (BUSS, 1992, p. 253, tradução nossa).

No entendimento de Buss, o mecanismo feminino de escolha de parceiro sexual é diferente do masculino. Ao comparar três textos relevantes 
do autor (BUSS, 1992; 2008; 2016), fica claro que esse entendimento ganhou desdobramentos e refinamentos com o passar dos anos. Isso é um indicativo dos esforços de expansão criativa do cinto de proteção.

No texto de 1992, a ideia-chave é que mulheres tendem a preferir parceiros "que demonstram habilidade e disposição para investir recursos em questões relacionadas à parentalidade, tais como comida, abrigo, território e proteção" (BUSS, 1992, p. 251, tradução nossa). No texto de 2008, encontramos importantes acréscimos: mulheres também consideram a força física e a saúde. "Ter o amor e o compromisso de um homem facilmente derrubável por outros homens na arena física teria sido problemático para mulheres ancestrais" (BUSS, 2008, p. 136, tradução nossa). No entanto, o amor, o compromisso e a força física "têm pouca serventia para a mulher se o seu companheiro adoece ou falece precocemente" (BUSS, 2008, p. 136, tradução nossa). O texto de 2016, por sua vez, explicita que o mecanismo feminino precisa avaliar (/computar) esses quesitos em conjunto: tais características vêm em pacote e "devem ser aceitas ou rejeitadas por completo. Isso requer, inevitavelmente, trade-offs" (BUSS, 2016, p. 80, tradução nossa).

Por que o mecanismo feminino evoluiu essas preferências? Buss sugere uma "história" evolucionária: imagine uma época na qual as mulheres não tinham preferências de parceiro sexual estabelecidas. Nessas condições, aquelas que se relacionavam com homens (i) mais capazes de prover e investir recursos em parentalidade, (ii) fisicamente mais fortes, e (iii) mais saudáveis... levavam vantagens sistemáticas sobre as demais (alimentação e educação da prole, proteção, reputação etc.). Ao longo de milhares de gerações, essa pressão seletiva acaba moldando um mecanismo psicológico que inclina as mulheres a preferir parceiros sexuais com tais atributos. Esse é, em pouquíssimas linhas, o lado evolucionário do mecanismo feminino de preferência sexual.

Qual é o cômputo, i.e., o processamento de informações que o mecanismo feminino faz? Resposta simplificada: ele recepciona (inputs) e avalia indicadores das características buscadas. Por exemplo: inteligência prática e disposição para o trabalho são indicadores da capacidade de acumular recursos; demonstrações de amor e expressões de bondade são indicadores da 
disposição para devotar recursos à prole; musculatura e dorso em V (peitoral maior que cintura) são indicadores de força física; e hábitos alimentares, aparência e odor da pele e estado de ânimo são indicadores de saúde.

Como o mecanismo feminino integra (/combina) esses indicadores? Essa questão ainda aguarda resposta definitiva. Sabe-se que mulheres economicamente bem-sucedidas atribuem importância superior ao sucesso econômico do potencial parceiro (PAWLOWSKI; DUNBAR, 1999a; CAMPOS; OTTA; SIQUEIRA, 2002). Sabe-se, também, que nos dias mais férteis do ciclo menstrual as mulheres sentem atração comparativamente maior por homens com musculatura definida e aparência saudável (PENTON-VOAK; PERRET, 2000; JOHNSTON et al., 2001). Em um estudo empírico particularmente interessante, Havlicek, Roberts e Flegr (2005) encontraram que, durantes os dias mais férteis do ciclo menstrual, mulheres preferem o odor de homens que tiveram alta pontuação no questionário de dominância de Goldberg (1999), disponível no International Personality Item Pool (IPIP) e no California Psychological Inventory (CPI). Os pesquisadores conduziram o estudo da seguinte forma: inicialmente, 48 homens (de 19 a 27 anos) responderam ao mencionado questionário de dominância e, adicionalmente, usaram por $24 \mathrm{~h}$ pequenas almofadas de algodão nas axilas. Essas almofadas foram, na sequência, apresentadas a 65 mulheres, que avaliaram o odor delas em termos de intensidade, sensualidade (sexiness) e masculinidade. Destas, 30 estavam no período mais fértil do ciclo menstrual. "Nossos resultados indicam que a dominância psicológica está associada à atratividade do odor. A preferência pelo odor de homens dominantes varia com o ciclo menstrual" (HAVLICEK, ROBERTS; FLEGR, 2005, p. 257, tradução nossa).

Passo agora a comentar o entendimento que Buss tem do mecanismo masculino de preferência sexual. Em uma frase, os homens evoluíram a tendência de preferir parceiras "de alta fertilidade" (BUSS, 1992, p. 249, tradução nossa). A história evolucionária que o pesquisador elabora para esse caso é a seguinte: 
Imagine uma circunstância na qual os machos humanos não tinham preferências sexuais além do reconhecimento da espécie, e se acasalavam com fêmeas aleatoriamente. Nessas condições, os machos que se acasalavam com fêmeas cuja idade estava fora dos anos reprodutivos ficavam sem descendência. Por outro lado, os machos que se acasalavam com fêmeas que estavam no pico da fertilidade desfrutavam de um sucesso reprodutivo relativamente alto. Ao longo de milhares de gerações, esta pressão de seleção moldará, nos homens, um mecanismo psicológico que os inclina a preferir acasalar com as fêmeas de alta fertilidade (BUSS, 1992, p. 249, tradução nossa).

Também aqui é pertinente indagar: qual é o cômputo, i.e., o processamento de informações que o mecanismo masculino faz? Buss (1992, p. 250) considera que ele foi moldado de maneira a processar indicadores de fertilidade: (i) características físicas, tais como pele suave e não maculada (unblemished), cabelos brilhantes, dentes brancos, ausência de cabelos grisalhos; (ii) gestos observáveis, tais como agilidade ao caminhar, movimentos diversos que sugerem alegria e energia; e (iii) reputação, em termos de testemunhos de outros quanto ao comportamento sexual.

No texto de 2008, a capacidade masculina de detectar se a mulher está na fase de ovulação (isto é, detectar quando o óvulo é lançado no útero e pode ser fertilizado) é melhor examinada. Essa questão ainda aguarda resposta definitiva. Não obstante, sabe-se que a pele da mulher ganha um brilho diferente durante a ovulação e que esse brilho é considerado sexualmente atraente em várias culturas (BERGHE; FROST, 1986). Sabese, também, que durante a ovulação os níveis de estrogênio aumentam e que isso diminui a relação cintura-quadril (waist-to-hip ratio - WHR). Homens tendem a sentir-se atraídos por baixa WHR (SYMONS, 1995).

Estudo empírico de Havlicek, Dvoraka, Bartos e Flegr (2006) constatou que homens tendem a preferir o odor de mulheres que estão em ovulação. Os pesquisadores conduziram um experimento com 42 homens (de 19 a 34 anos), que avaliaram o odor de almofadas de algodão que haviam estado 
por $24 \mathrm{~h}$ nas axilas de 12 mulheres (de 20 a 27 anos; em ciclo menstrual regular; sem uso de contraceptivos hormonais ou químicos). Ao todo, foram feitas 5 (cinco) rodadas de avaliações (uma por semana, por cinco semanas consecutivas). Em cada rodada, o participante era instruído a cheirar a almofada e, em seguida, registrar a sua percepção quanto à intensidade, prazer, atratividade sexual e feminilidade do odor, sempre em uma escala de sete pontos. "Nossos resultados mostram que os índices de prazer e atratividade sexual atribuídos aos odores das axilas são baixos durante a menstruação e altos no período folicular, quando a probabilidade de concepção é alta" (HAVLICEK; DVOROKA; BARTOS; FLEGR, 2006, p. 85, tradução nossa).

Até aqui, apresentei sucintamente os dois mecanismos de preferência sexual (feminino e masculino) propostos por Buss. O próximo passo - crucial para o presente empreendimento - é atentar para as predições e ver se elas encontram corroboração empírica. No texto de 1992, Buss é particularmente claro em suas predições:

Visto que os machos valorizam indícios da capacidade reprodutiva [...], espera-se que as fêmeas mintam a sua idade, alterem sua aparência e ocultem suas atividades sexuais anteriores. Visto que fêmeas valorizam disposição e habilidade para devotar recursos, espera-se que os machos exagerem suas posses, inflacionem sua disposição ao compromisso e finjam amorosidade para induzir a fêmea ao acasalamento (BUSS, 1992, p. 252, tradução nossa).

Relembrando: estamos examinando aspectos do cinto de proteção do programa de pesquisa - lugar dos modelos e hipóteses empíricas refutáveis. A questão é, reitero, vincular o núcleo do programa a dados empíricos. Mediante predições originais, um programa de pesquisa se candidata ao status "empiricamente progressivo".

De fato, as predições de Buss encontraram corroboração empírica. Greenless e McGrew (1994) analisaram 1.000 anúncios heterossexuais 
(lonely hearts advertisements; 706 de homens e 297 de mulheres) publicados na coluna "Eye Love" do jornal britânico Private Eye, entre 1987-1989. Minuciosa análise do conteúdo desses anúncios levou os pesquisadores a confirmar que: (1) mulheres, mais do que os homens, ocultam a sua idade; (2) mulheres, mais do que homens, buscam indícios de segurança financeira no parceiro; (2) mulheres, mais do que homens, solicitam investimentos do parceiro em termos de tempo, energia e afetividade como elementos básicos para a relação; (3) homens, mais do que mulheres, anunciam disposição para investir recursos financeiros no relacionamento; (4) homens, mais do que mulheres, buscam parceiras mais jovens do que eles próprios; (5) homens, mais do que mulheres, buscam e valorizam a aparência física das parceiras; (6) mulheres, mais do que homens, anunciam aspectos da sua aparência física; (7) homens, mais do que mulheres, anunciam hobbies seus que refletem status e riqueza, bem como habilidades que indicam a sua capacidade de alta renda; e (8) mulheres, mais do que homens, anunciam hobbies seus que refletem vigor físico e saúde.

Pawlowski e Dunbar (1999b) divulgaram resultados de um estudo similar, que analisou 720 anúncios de homens e 739 anúncios de mulheres publicados na coluna "Soulmates" do jornal The Observer entre 1995 e 1996. Os pesquisadores encontraram que: (1) mulheres são significativamente menos propensas a declarar a própria idade; (2) mulheres que não anunciam a própria idade especificam mais características buscadas no parceiro. Por conta disso, tais anúncios passam a impressão de serem de "moças de 20 anos que são capazes de apresentar grandes exigências sem terem muito a oferecer em compensação (além da juventude)" (PAWLOWSKI; DUNBAR, 1999b, p. 63, tradução nossa). E, (3) mulheres que não anunciam a própria idade são mais exigentes em termos de atratividade física e habilidades sociais do potencial parceiro. Quanto a isso, os pesquisadores conjecturam que "mulheres mais velhas não anunciam a própria idade a fim de pleitear parceiros mais qualificados" (PAWLOWSKI; DUNBAR, 1999b, p. 65, tradução nossa).

Mulheres tendem a ocultar as suas atividades sexuais anteriores. Fisher (2013) confirmou essa hipótese através de um estudo empírico com a 
metodologia bogus pipeline (um falso detector de mentiras). Polêmica do ponto de vista ético, essa técnica assume que "quando os participantes acreditam que os pesquisadores têm meios para verificar a verdade das declarações que estão sendo dadas, eles tendem a ser mais honestos nas suas respostas" (FISHER, 2013, p. 402, tradução nossa). Fisher coletou dados de 293 universitários ( 160 mulheres e 133 homens, de 18 a 25 anos, todos solteiros e autodeclarados heterossexuais), que foram randomicamente divididos em dois grupos: "Bogus Pipeline" e "Non-Pipeline". Todos os participantes responderam anonimamente ao mesmo questionário escrito, sozinhos, em uma sala reservada. Os participantes do grupo "Bogus Pipeline" estavam conectados ao falso detector de mentiras enquanto respondiam. Os resultados corroboram as predições de Buss (1992). Quanto ao número de parceiros sexuais: os homens do grupo "Bogus Pipeline" reportaram, em média, 1.96 parceiras; já os homens do grupo "Non-Pipeline" reportaram, em média, 3.25 parceiras. Mulheres do grupo "Bogus Pipeline" reportaram, em média, 3.35 parceiros; já as mulheres do grupo "Non-Pipeline" reportaram, em média, 2.70 parceiros. Quanto ao número de parceiros de uma só vez (one-time partners): homens do "Bogus Pipeline" = 0.79 em média; homens "Non-Pipeline" = 1.12 em média; Mulheres do "Bogus Pipeline" = 1.01 em média; mulheres "Non-Pipeline" $=0.82$ em média.

Em estudo recém-publicado, Sohn (2017) analisou o comportamento de homens sul-coreanos no que tange a um fenômeno específico daquela cultura: a prática de comprar (literalmente) uma noiva de um país pobre. "Inspirados pela psicologia evolucionária, nós levantamos a hipótese de que homens que compram a sua noiva casam com mulheres jovens e férteis, independentemente de sua própria idade, e que outros homens seguem o padrão usual (i.e., homens mais velhos casam com mulheres mais velhas)" (SOHN, 2017, p. 59, tradução nossa). Mediante análise de todos os registros de matrimônio de 2010 a 2014 na Coréia do Sul, o pesquisador confirmou essa hipótese.

O estudos empíricos comentados nos últimos parágrafos corroboram a predição de Buss, antes apresentada. Nos termos de Lakatos, o crescimento teórico do programa antecipou o crescimento empírico. Por isso, é 
acertado dizer que a modularidade massiva é um programa empiricamente progressivo. No que segue, comento outros dois desenvolvimentos que suportam a mesma conclusão.

\subsection{Nojo sexual}

Fessler e Navarrete (2003) articularam uma hipótese evolucionária acerca do nojo no âmbito da sexualidade. ${ }^{15}$ Para os autores, o nojo sexual é uma adaptação que funciona como um inibidor de relações sexuais biologicamente subótimas, isto é, relações que são avaliadas (/computadas) como tendo potencial de reduzir o fitness.

Tal como no caso do mecanismo de preferência sexual de Buss, comentado na seção anterior, é possível aqui desdobrar uma história que evidencia pressões que, ao longo do tempo evolucionário, forjaram um mecanismo específico que regula o nojo sexual. Essa história deve mencionar os "custos" de relações e reprodução que reduz of fitness. Considere, a título de exemplo, os custos evolutivos do incesto.

Ao invés de alongar a história das pressões e dos custos evolutivos de relações subótimas, permita-me avançar logo para as predições de Fessler e Navarrete (2003). Com efeito, esses pesquisadores também são particularmente claros nesse quesito: "Se o nojo sexual é uma adaptação destinada a reduzir a probabilidade de comportamentos sexuais subótimos, então o nojo sexual [...] deve variar ao longo do ciclo menstrual, em função do risco de concepção" (FESSLER; NAVARRETE, 2003, p. 408, tradução nossa). Essa variação, eles dizem, deve ser notável apenas no domínio sexual, e não aparecer em outros domínios nos quais o nojo ocorre (ex. certos alimentos, animais, questões de higiene, morte).

Vamos retomar mais uma vez: núcleo do programa - a ideia de que a mente humana é toda organizada por módulos de domínio específico - levou

15 Os autores usam a expressão "sexual disgust", uma emoção que elimina/reduz o apetite ou desejo sexual. Considero conveniente traduzir por nojo ao invés de desgosto. 
à proposição de um módulo que evoluiu para regular o nojo sexual e, nesse plano, à predição de que as mulheres devem ser mais propensas a sentir nojo sexual durante os dias de maior fertilidade. Essa é, nitidamente, uma maneira criativa de vincular o núcleo a dados empíricos. Por meio de esforços desse tipo, o cinto de proteção se expande e o programa de pesquisa avança.

A predição de Fessler e Navarrete (2003) encontrou corroboração. Os próprios pesquisadores desenharam um experimento que avalia variações do nojo em 8 (oito) domínios: comidas, animais, fezes, sexo, sangue e mutilações corporais, morte, higiene, e pensamento mágico. Participaram do experimento 307 mulheres de 18 a 45 anos, consideradas saudáveis e que não faziam uso de contraceptivos hormonais ou químicos. Os dados confirmam a predição: "a sensibilidade para o nojo no domínio do sexo, e apenas no domínio do sexo, está positivamente correlacionada com o risco presumido de concepção, tal como este é estimado pela própria pessoa com base em seu ciclo menstrual" (FESSLER; NAVARRETE, 2003, p. 412, tradução nossa).

As pesquisas em torno do nojo estão em franco desenvolvimento na comunidade da psicologia evolucionária. Tybur, Lieberman e Griskevicius (2009) propõe que o nojo funciona para resolver três problemas evolucionários qualitativamente distintos: patogenias, sexo e moralidade.

Nós propomos que o nojo evoluiu para motivar soluções comportamentais para múltiplos problemas adaptativos distintos: evitar substâncias tidas como agentes causadores de doenças no mundo primitivo [...]; evitar parceiros e comportamentos sexuais capazes de reduzir o sucesso reprodutivo no longo prazo; e evitar indivíduos que nos infligem custos sociais" (TYBUR; LIEBERMAN; GRISKEVICIUS, 2009, p. 105, tradução nossa).

No que tange ao nojo sexual, especificamente, os autores sublinham que ele evoluiu para "solucionar o problema de evitar parceiros biologicamente onerosos [biologically costly mates]" (2009, p. 106, tradução nossa). Interpreto que há um avanço teórico nesse ponto - recorde o leitor que, em programas 
progressivos, o avanço teórico antecipa o avanço empírico -, uma vez que há aspectos biológicos de duas categorias: genéticos (compatibilidade e incompatibilidade genética) e aspectos fenotípicos visíveis (aparência física, musculatura, rosto...). Consequentemente, faz sentido supor que o mecanismo que regula o nojo sexual funciona no sentido de evitar parceiros geneticamente onerosos.

A fim de precisar os três domínios de nojo, os autores conduziram quatro estudos empíricos, todos com questionários escritos. Ao invés de comentar detalhes desses estudos, interessa-me destacar que esse trabalho resultou em uma nova escala para o nojo: a Three-Domain Disgust Scale - TDDS (TYBUR; LIEBERMAN; GRISKEVICIUS, 2009, p. 122). Essa escala é composta por 21 itens ( 7 itens de cada domínio), que são avaliados em uma escala de o a 6 (onde $o$ = nada nojento e 6 = extremamente nojento). "A TDDS que nós desenvolvemos providencia uma via empiricamente válida para explorar diferenças individuais na sensibilidade para o nojo sexual e moral [...], em adição ao nojo patógeno" (TYBUR; LIEBERMAN; GRISKEVICIUS, 2009, p. 117, tradução nossa). ${ }^{16}$

Em trabalho posterior (TYBUR et al., 2013), esses pesquisadores avançam na elucidação da dimensão evolucionária e da dimensão computacional do nojo em cada um dos três domínios da TDDS.

Para cada domínio funcional [patógeno, sexual e moral], nós produzimos descrições em dois níveis de análise. A primeira, que decifra a função, requer a descrição das condições históricas recorrentes que levaram à evolução da emoção [o nojo] e a subsequente manutenção. [...] nosso segundo nível de análise, o nível da estrutura do processamento de informações, especifica como esse recurso [mecanismo] opera em um organismo individual (TYBUR et al., 2013, p. 67, tradução nossa).

\footnotetext{
16 Desde a sua proposição, em 2009, a TDDS alavancou muitos estudos empíricos. Ao leitor interessado no nojo no domínio da moral, recomendo Eskine, Kacinik e Prinz (2011), Kelly (2011) e Chapman e Anderson (2014). Quanto ao nojo no domínio patógeno, conferir Oaten, Stevenson e Case (2009) Curtis, Barra e Aunger (2011), Davey (2011) e Tybur et al. (2015).
} 
Esse trabalho é interessantíssimo, uma vez que ele explicita, de modo inequívoco, a sintonia com o núcleo do programa de pesquisa. Permita-me resgatar apenas na dimensão computacional do mecanismo que regula o nojo sexual (TYBUR et al., 2013, p. 71-73, tradução nossa). Quanto aos inputs, eles são oriundos dos módulos perceptivos. Basicamente, o mecanismo recepciona indicadores perceptuais relativos à compatibilidade genética e ao valor do potencial parceiro. Essas informações são então processadas. O cômputo que o mecanismo faz integra os inputs e compara o resultado (expected fitness outcome) de evitar versus o resultado de ter sexo com esse parceiro. Em seguida, o mecanismo usa esse resultado para ativar os processos fisiológicos e psicológicos de evasão sexual. Assim, “o nojo sexual é um output de um processo computacional que estima o valor sexual de um indivíduo" (TYBUR et al., 2013, p. 73, tradução nossa). Importa mencionar, também, que o mecanismo é computacionalmente regulado de modo tal que a compatibilidade genética se sobrepõe a traços físicos, recursos materiais e status social.

Al-Shawaf, Lewis e Buss (2015) dedicam-se a compreender melhor a relação do nojo sexual com estratégias de acasalamento a curto prazo, que não visam qualquer compromisso duradouro (short-term mating strategies). Considerando o exposto nos parágrafos anteriores, fica fácil compreender a questão-chave desse trabalho: será que o nojo sexual pode ser estratégica e funcionalmente reduzido para facilitar relações sexuais casuais? Esses autores encontraram que "uma orientação na direção de um acasalamento a curto prazo está associada à supressão do nojo sexual, mas não [à supressão] do nojo patógeno e moral" (AL-SHAWAF; LEWIS; BUSS, 2015, p. 203, tradução nossa).

Sherlock et al. (2016) dedicam-se à difícil tarefa de distinguir aspectos genéticos de aspectos ambientais associados ao nojo. Para tanto, eles conduziram um experimento com mulheres finlandesas gêmeas e suas irmãs, cujas informações genéticas já se encontravam em uma base de dados oriunda de estudos anteriores. Essas pessoas foram contatadas por e-mail e convidadas a responder individualmente ao questionário TDDS (TYBUR et al., 2009). Responderam 544 gêmeas idênticas (univitelinas) 
e 497 gêmeas não idênticas (bivitelinas). Adicionalmente, responderam também 88 irmãs de gêmeas univitelinas e 82 irmãs de gêmeas bivitelinas. "Usando uma grande amostra de gêmeas mulheres e suas irmãs, nós observamos que diferenças individuais na sensibilidade para o nojo são substancialmente hereditárias. [...] Tal como no nojo patogênico, o ambiente compartilhado pelas gêmeas teve pouco efeito na variação do nojo sexual e moral" (SHERLOCK et al., 2016, p. 47, tradução nossa).

A literatura empírica mencionada nos últimos parágrafos permite inferir que a hipótese de um módulo dedicado ao nojo sexual (FESSLER; NAVARRETE, 2003) constitui genuíno avanço do conhecimento científico. Por essas vias o programa de pesquisa avança, pois o trabalho de vincular o núcleo a dados empíricos foi bem-sucedido. Temos, então, mais uma razão para afirmar que a modularidade massiva é um programa empiricamente progressivo.

\subsection{Detecção de trapaceiros}

Cosmides e Tooby (1992) propuseram a existência de um mecanismo cognitivo dedicado à detecção de trapaceiros (cheater detection) na vida social. Genericamente, trapaceiro éo indivíduo que aceita, mas viola, uma regra do tipo "Se P, então $Q$ ". (e.g. "Se você usufruir $C$, deve arcar com a contrapartida $D$ ").

Trapacear é uma violação de um contrato social. Um trapaceiro é um indivíduo que se beneficia ilicitamente ao apropriar-se de algo sem satisfazer a contrapartida pressuposta e esperada pela outra parte contratante. [...] Pessoas possuem adaptações cognitivas especializadas para raciocinar sobre contratos sociais. [...] Pessoas possuem capacidades inferenciais especializadas para a detecção de trapaceiros (COSMIDES;TOOBY, 1992, p. 180, tradução nossa).

Depois de uma longa especulação das pressões evolutivas que podem ter contribuído para o amadurecimento desse módulo, Cosmides e 
Tooby (1992, p. 205, tradução nossa) sublinham: “O raciocínio humano é bem projetado para detectar violações de regras condicionais quando estas podem ser interpretadas como trapaça em contrato social". Isso não significa que sejamos bons com regras condicionais em geral. O que está sendo defendido é uma especialização: somos bons com regras condicionais em situações de trapaça. Para os autores, a interpretação mais parcimoniosa dessa capacidade consiste em considerá-la um módulo com um conjunto de características específicas. Em forma de predição, Cosmides e Tooby (1992) enumeram essas características:

(1) Os algoritmos que governam o raciocínio sobre contratos sociais incluem procedimentos de inferência especializados na detecção de trapaças. (2) Os procedimentos de detecção de trapaceiros não conseguem detectar violações que não correspondem a trapaças (tais como erros). (3) Os algoritmos que governam o raciocínio sobre contratos sociais operam mesmo em situações desconhecidas. (4) A definição de trapaça que eles portam depende da perspectiva do indivíduo. (5) A representação dos custos e benefícios de um contrato social é computada com a mesma qualidade para ambas as partes. (6) Eles não podem operar de modo a detectar trapaceiros, a menos que uma regra que representa os custos e benefícios de um contrato social tenha sido estabelecida. (7) Eles incorporam procedimentos implícitos especificados pela teoria de computação (e.g., "Se você tem o benefício, então você é obrigado a arcar com o custo" implica "Se você arcou com o custo, então você tem direito ao benefício"). (8) Eles não incluem procedimentos de detecção de altruismo (COSMIDES; TOOBY, 1992, p. 205-206, tradução nossa).

Cumpre notar que esse conjunto de predições especifica o funcionamento (o lado computacional) do módulo cheater detector. Será que essas predições possuem corroboração empírica? Essa pergunta vem 
sendo debatida há mais de 20 anos. Nesse plano, dados produzidos com o Wason Selection Task vêm sendo objeto de calorosa discussão. Vejamos.

A versão padrão do Wason Selection Task é simples: primeiro, o/a participante é instruído acerca da regra condicional "SeP, então Q". Em seguida, 4 cartas são apresentadas (Figura 1). Explica-se ao participante que cada uma dessas cartas contém informação na frente e no verso, embora o/a participante visualize apenas um dos lados. Imagine as cartas sobre uma mesa, assim:

Figura 1 - Versão Padrão do Wason Selection Task

(1)

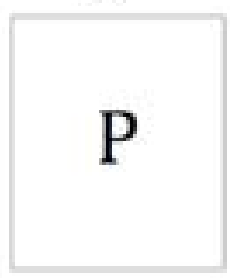

(2)

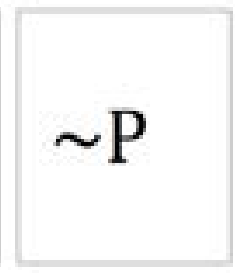

[3)

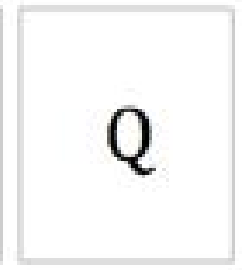

(4)

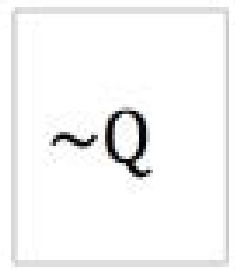

Fonte: Elaborada pelo autor com base em Cosmides e Tooby (1992, p. 182).

$\mathrm{Na}$ continuidade, pergunta-se ao participante: Quais dessas cartas você precisaria virar (i.e., conferir o outro lado) a fim de saber se alguma dessas quatro instâncias viola a regra "Se $P$, então $Q$ "? Gize-se: o/a participante está sendo convidado/a a detectar casos que violam a regra. Ora, ela é violada quando $\mathrm{P}$ está presente, mas $\mathrm{Q}$ não está. Logo, as cartas cujo verso precisa ser conferido são (1) e (4). Embora o teste seja simples, cerca de $90 \%$ das pessoas falham em apontar a resposta correta (EVANS; NEWSTEAD; BYRNE, 1993; NEYS, 2006). Isso sugere que a nossa capacidade de raciocinar com condicionais é relativamente limitada. Inclusive demandas simples como essa facilmente nos deixam confusos e incertos. 
Por outro lado, a capacidade de raciocinar com condicionais melhora significativamente quando a regra em questão (Se P, então Q) diz respeito a algum aspecto da vida social. (Regras do tipo "Se você usufruir o benefício A, você precisa cumprir com a contrapartida B"). Considere, por exemplo, o Wason Selection Task aplicado com a regra "Se X usou o carro, então X precisa abastecê-lo". O teste segue exatamente a mesma lógica. Eis as cartas (Figura 2):

Figura 2 - - Wason Selection Task na detecção de trapaceiros

(1)

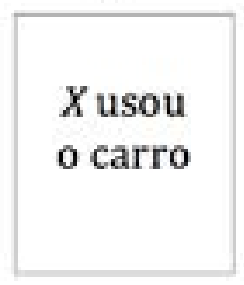

(2)

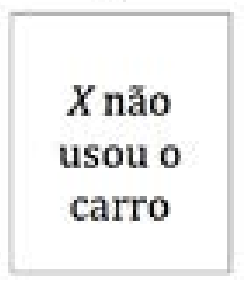

(3)

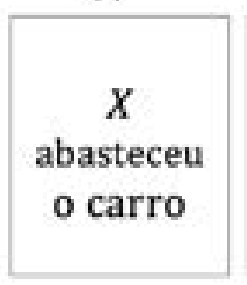

(4)

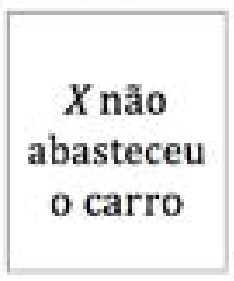

Fonte: Elaborada pelo autor com base em Cosmides e Tooby (1992, p. 182).

Nessa versão, em torno de $75 \%$ das pessoas acertam: para saber se a regra "Se X usou o carro, então X precisa abastecê-lo" foi violada, é preciso conferir o verso das cartas 1 e 4 (VAN LIER; REVLIN; DE NEYS, 2013). Essa melhoria impressionante vai ao encontro das predições enumeradas por Cosmides e Tooby (1992). Ela pode, por isso, ser interpretada como uma corroboração da hipótese de um módulo de detecção de trapaceiros.

Evidências adicionais foram produzidas por Sugiyama et al. (2002). Por meio de um estudo empírico cross-cultural, esses pesquisadores mostraram que indivíduos da tribo dos Shiwiar, coletores-horticultores da Amazônia equatoriana, possuem competência similar a de graduandos de Harvard no Wason Selection Task com regra condicional relativa à vida social (índice de acerto acima de 80\%). "Tal como os estudantes de Harvard, 
os Shiwiar quase sempre escolheram as cartas corretas para detectar trapaceiros" (SUGIYAMA et al., 2002, p. 11539-11540, tradução nossa).

Harris, Núñez e Brett (2001) adaptaram e aplicaram o teste em crianças inglesas e nepalesas de 3 a 7 anos de idade. A adaptação consistiu em uma história, na qual dois protagonistas concordam em colaborar mutuamente em uma situação. "Tanto as crianças britânicas quanto as do Nepal distinguiram corretamente (1) quando um protagonista trapaceou o acordo e (2) quando ambos os protagonistas cumpriram o acordo" (HARRIS, NÚÑES; BRETT, 2001, p. 757, tradução nossa).

Com fMRI, Ermer et al. (2006) compararam atividade cerebral quando se raciocina a partir de regras de precaução (precautionary rules - e.g. "Se você se envolver com a atividade perigosa $X$, então você deve tomar a precaução $Y^{\prime \prime}$ ) e quando se raciocina a partir de regras relativas à vida social (social exchange rules - e.g. "Se você usufruir o benefício $A$, você precisa cumprir com a contrapartida B"). Embora compartilhem várias características relevantes - ambas as regras são condicionais, deônticas e envolvem utilidade subjetiva -, os correlatos neuronais são distintos: "a neuroimagem mostra que o raciocínio sobre intercâmbio social ativa áreas cerebrais que não são ativadas pelo raciocínio sobre regras de precaução, e vice-versa" (ERMER et al., 2006, p. 197, tradução nossa). Essa é uma evidência neuronal a favor da existência de um módulo específico de detecção de trapaceiros. Com efeito, essas diferenças neuronais não deveriam aparecer se esses dois raciocínios, tão similares, fossem operados por um único mecanismo de alcance maior. Nas palavras dos autores:

Diferentes padrões de ativação neural para contratos sociais e precauções não deveriam existir se teorias de domínio geral do raciocínio estivessem corretas. De acordo com essas teorias, as regras de precaução e as de troca social são apenas exemplos de uma classe mais geral de regras condicionais, de modo que ambas são operadas pela mesma maquinaria neurocomputacional (ERMER et al., 2006, p. 204, tradução nossa). 
Van Lier, Revlin e De Neys (2013) reportam três experimentos desenhados com a intenção de aferir a automaticidade do módulo de detecção de trapaceiros. Os resultados levam os pesquisadores a escrever: “Nós mostramos que a detecção de trapaceiros opera de modo automático e independentemente dos recursos cognitivos gerais. Esses resultados falseiam a ideia de que todos os raciocínios são baseados em um mecanismo geral". Por conta disso, prosseguem os pesquisadores, "nossos achados dão credibilidade à proposta evolucionária de um módulo automático de detecção de trapaceiros" (VAN LIER; REVLIN; DE NEYS, 2013, p. e53827, tradução nossa, grifo nosso).

Considerando as evidências comentadas ao longo dos últimos parágrafos, concluo que a hipótese de um módulo cheater detector (COSMIDES; TOOBY, 1992) encontrou corroboração empírica. Assim, também esse desenvolvimento nos permite dizer que o programa da modularidade massiva é empiricamente progressivo.

\section{Considerações finais}

Vimos, ao longo dessas páginas, que a modularidade massiva pode ser descrita como um programa de pesquisa empiricamente progressivo, no sentido que Lakatos conferiu a essa expressão. Pesquisadores ligados a essa escola de pensamento têm conseguido vincular o núcleo do programa - a ideia de que a nossa mente é toda organizada por módulos de domínio específico que evoluíram para a solução de problemas de processamento de informação - a dados empíricos.

Quer isso significar que a modularidade massiva é uma teoria verdadeira? Não exatamente. O melhor que se pode dizer, nesse ponto, é que teorias científicas são aproximadas. Sob o prisma de Lakatos, teorias são programas de pesquisa que se mantêm enquanto houver pesquisadores que se dedicam ao trabalho de expandir e sofisticar o cinto de proteção. Quando esse trabalho é interrompido, o programa para de crescer e, consequentemente, deixa de gerar predições novas. Nesse caso, temos o que Lakatos chamou "estagnação" e "degeneração". 
Diversos outros aspectos interessantes do cinto de proteção da modularidade massiva não foram abordados aqui. Além de identificar e descrever módulos, é preciso avançar no sentido de compreender como eles se comunicam uns com os outros (inputs e outputs). Outra linha de trabalho diz respeito à acomodação de grandes questões, tais como o fenômeno da consciência, a capacidade criativa, a memória e outras.

\section{Referências}

AL-SHAWAF, L.; LEWIS, D.; BUSS, D. Disgust and mating strategy. Evolution \& Human Behavior, [S. l.], v. 36, n. 3, p. 199-205, 2015. Doi: http://dx.doi. org/10.1016/j.evolhumbehav.2014.11.003

BARRETT, H. Modules in the flesh. In: GANGESTAD, S.; SIMPSON, J. (ed.) The evolution of mind: fundamental questions and controversies. New York: Guilford Press, 2007. p. 161-170.

BERGHE, P.; FROST, P. Skin color preference, sexual dimorphism and sexual selection: a case of gene culture co-evolution? Ethnic and Racial Studies, [S. I.], v. 9, n. 1, p. 87-113, 1986. Doi: http://dx.doi.org/10.1080/01419870.1986.9993516 BJORKLUND, D. In search of a metatheory for cognitive development (or, Piaget is dead and I don't feel so good myself.) Child Development, [S. I.], v. 68, n. 1, p. 144-148, 1997. Doi: http://dx.doi.org/10.1111/j.1467-8624.1997.tb01932.x

BROWN, R. What evolvability really is. British Journal of Philosophy of Science, [S. l.], v. 65, n. 03, p. 549-572, 2014. Doi: https://doi.org/10.1093/bjps/axto14

BUSS, D. Mate preference mechanisms: consequences for partner choice and intrasexual competition. In: BARKOW, J.; COSMIDES, L.; TOOBY, J. (ed.) The adapted mind: evolutionary psychology and the generation of culture. New York; Oxford: Oxford University Press, 1992. p. 249-266.

BUSS, D. The evolution of desire: strategies of human mating. 3. ed. revised and updated. New York: Basic Books, 2016. https://doi.org/10.1017/ s0730938400018700

BUSS. D. Evolutionary psychology: the new science of the mind. 3. ed. Boston: Pearson Education, 2008.

CAIN, M. J. Fodor: language, mind and philosophy. Cambridge, UK; Malden, MA: Polity Press; Blackwell, 2002. 
CAMPOS, L.; OTTA, E.; SIQUEIRA, J. Sex differences in mate selection strategies: content analyses and responses to personal advertisements in Brazil. Evolution and Human Behavior, [S. l.], v. 23, n. 2, p. 395-406, 2002. Doi: http:// dx.doi.org/10.1016/S1090-5138(01)00092-7

CARRUTHERS, P. On Fodor-fixation, flexibility and human uniqueness. Mind and Language, [S. l.], v. 23, n. 3, p. 293-303, 2008. Doi: http://dx.doi. org/10.1111/j.1468-0017.2008.00344.x

CARRUTHERS, P. The architecture of mind. Oxford: Oxford University Press, 2006.

CHAPMAN, H.; ANDERSON, A. Trait physical disgust is related to moral judgments outside of the purity domain. Emotion, [S. l.], v. 14, n. 2, 341-348, 2014. Doi: http://dx.doi.org/10.1037/a0035120

COSMIDES L.; TOOBY, J. Cognitive adaptations for social exchange. In: BARKOW, J.; COSMIDES, L.; TOOBY, J. (ed.). The adapted mind: evolutionary psychology and the generation of culture. Oxford: Oxford University Press, 1992. p. 163-228. https://doi.org/10.1017/s0730938400018700

COSMIDES, L.; TOOBY, J. Origins of domain specificity: the evolution of functional organization. In: HIRSCHFELD, L.; GELMAN, S. (ed.). Mapping the mind: domain specificity in cognition and culture. Cambridge: Cambridge University Press, 1994. p. 85-116. https://doi.org/10.1017/cbo9780511752902.005

COSMIDES, L.; TOOBY, J.; BARKOW, J. Introduction: evolutionary psychology and conceptual integration. In: BARKOW, J.; COSMIDES, L.; TOOBY, J. (ed.). The adapted mind: evolutionary psychology and the generation of culture. New York: Oxford University Press, 1992. p. 03-18.https://doi.org/10.1017/ s0730938400018700

CURTIS, V.; BARRA, M.; AUNGER, R. Disgust as an adaptive system for disease avoidance behaviour. Philosophical Transactions of the Royal Society $B$, [S. l.], v. 366, n. 1563, p. 389-401, 2011. Doi: http://dx.doi.org/10.1098/rstb.2010.0117 DAVEY, G. Disgust: the disease-avoidance emotion and its dysfunctions. Philosophical Transactions of the Royal Society B, [S. l.], v. 366, n. 1583, p. 3453-3465, 2011. Doi: http://dx.doi.org/10.1098/rstb.2011.0039

ERAñA, A. Dual process theories versus massive modularity hypotheses. Philosophical Psychology, [S. l.], v. 25, n. 6, p. 855-872, 2012. Doi: http://dx.doi. org/10.1080/09515089.2011.631994 
ERMER, E.; GUERIN, S.; COSMIDES, L.; TOOBY, J.; MILLER, M. Theory of mind broad and narrow: reasoning about social exchange engages ToM areas, precautionary reasoning does not. Social Neuroscience, [S. I.], v. 1, n. 3-4, p. 196-219, 2006. Doi: https://doi.org/10.1080/17470910600989771

ESKINE, K.; KACINIK, N.; PRINZ, J. A bad taste in the mouth: Gustatory disgust influences moral judgment. Psychological Science, [S. I.], v. 22, n. 3, p. 295-299, 2011. Doi: http://dx.doi.org/10.1177/0956797611398497

EVANS, J.; NEWSTEAD, S.; BYRNE, R. Human reasoning: the psychology of deduction: Hove, UK: Lawrence Erlbaum Associates Ltd., 1993.

FESSLER, D.; NAVARRETE, D. Domain-specific variation in disgust sensitivity across the menstrual cycle. Evolution and Human Behavior, [S. I.], v. 24, n. 6, p. 406-417, 2003. Doi: http://dx.doi.org/10.1016/S1090-5138(03)00054-0

FISHER, T. Gender roles and pressure to be truthful: the bogus pipeline modifies gender differences in sexual but not non-sexual behavior. Sex Roles, [S. I.], v. 68, n. 7-8, p. 401-414, 2013. Doi: https://doi.org/10.1007/s11199-013-0266-3 FODOR, J. The mind doesn't work that way. Cambridge: MIT Press, 2000.

FODOR, J. The modularity of mind. Cambridge: MIT Press, 1983.

FORSTER, M. Prediction. In: CURD, M.; PSILLOS, S. (ed.) The Routledge companion to philosophy of science. 2. ed. London; New York: Routledge, 2014. p. 449-457.

FRASER, H. Modularity and evolutionary constraint on proteins. Nature Genetics, [S. l.], v. 37, n. 4, p. 351-352, 2005. Doi: https://doi.org/10.1038/ng1530

GALLISTEL, C. The replacement of general-purpose learning models with adaptively specialized learning modules. In: GAZZANIGA, M. (ed.) The cognitive neurosciences. 2. ed. Cambridge: MIT Press, 2000. p. 1179-1191.

GOLDBERG, L. A broad-bandwidth, public domain, personality inventory measuring the lower-level facets of several five-factor models. In: MERVIELDE, I.; DEARY, I.; DE FRUYT, F.; OSTENDORF, F. (ed.) Personality psychology in Europe. Tilburg: Tilburg University Press, 1999. p. 07-28. https://doi.org/10.1016/ s0191-8869(99)00216-0

GREENLESS, I.; MCGREW, W. Sex and age differences in preferences and tactics of mate attraction: analysis of published advertisements. Ethology and Sociobiology, [S. l.], v. 15, n. 2, p. 59-72, 1994. Doi: http://dx.doi. org/10.1016/0162-3095(94)90017-5 
HAN, J.; BERTIN, N.; HAO, T.; GOLDBERG, D.; BERRIZ, G.; ZHANG, L.; DUPUY, D.; WALHOUT, A.; CUSICK, M.; ROTH, F.; VIDAL, M. Evidence for dynamically organized modularity in the yeast protein-protein interaction network. Nature, [S. l.], v. 430, p. 88-93, 2004. Doi: http://dx.doi.org/10.1038/nature02555

HARRIS, P.; NÚÑEZ, M.; BRETT, C. Let's swap: early understanding of social exchange by British and Nepali children. Memory \& Cognition, [S. l.], v. 29, n. 5, p. 757-764, 2001. Doi: http://dx.doi.org/10.3758/BF03200478

HARTWELL, L.; HOPFIELD, J.; LEIBLER, S.; MURRAY, A. From molecular to modular cell in biology. Nature, [S. l.], v. 402, C47-C52, 1999. https://doi. org/10.1038/35011540

HAVLICEK, J.; DVORAKOVA, R.; BARTOS, L.; FLEGR, J. Non-advertised does not mean concealed: body odour changes across the human menstrual cycle. Ethology, [S. l.], v. 112, n. 1, p. 81-90, 2006. Doi: http://dx.doi.org/10.1111/j. 1439-0310.2006.01125.x

HAVLICEK, J.; ROBERTS, S.; FLEGR, J. Women's preference for dominant male odour: effects of menstrual cycle and relationship status. Biology Letters, [S. l.], v. 1, p. 256-259, 2005. Doi: http://dx.doi.org/10.1098/rsbl.2005.0332

HE, J.; DEEM, M. Hierarchical evolution of animal body plans. Developmental Biology, [S. l.], v. 337, n. 1, p. 157-161, 2010. Doi: https://doi.org/10.1016/j. ydbio.2009.09.038

HILLS, T. Animal foraging and the evolution of goal-directed cognition. Cognitive Science, [S. l.], v. 30, n. 01, p. 03-41, 2006. Doi: https://doi.org/10.1207/ s15516709cogoooo_50

JOHNSTON, V.; HAGEL, R.; FRANKLIN, M.; FINK, B.; GRAMMER, K. Male facial attractiveness: evidence for hormone-mediated adaptive design. Evolution and Human Behavior, [S. l.], v. 22, n. 4, p. 251-267, 2001. Doi: http://dx.doi. org/10.1016/S1090-5138(01)00066-6

KELLY, D. Yuck: the nature and moral significance of disgust. Cambridge, MA: MIT Press, 2011.

KENNAIR, L. Challenging design: how best to account for the world as it really is. Zygon, [S. l.], v. 38, n. 3, p. 543-558, 2003. Doi: http://dx.doi. org/10.1111/1467-9744.00520

KITANO, H. Biological robustness. Nature Reviews Genetics, [S. l.], v. 5, p. 826-837, 2004. Doi: http://dx.doi.org/10.1038/nrg1471 
KITANO, H. Towards a theory of biological robustness. Molecular Systems Biology, [S. l.], v. 137, n. 3, p. 01-07, 2007. Doi: https://dx.doi.org/10.1038/ msb4100179

KLINGENBERG, C. Morphological integration and developmental modularity. Annual Review of Ecology, Evolution and Systematics, [S. l.], v. 39, p. 115-132, 2008. Doi: https://doi.org/10.1146/annurev.ecolsys.37.091305.110054

KRAUSE, A.; FRANK, K.; MASON, D.; ULANOWICZ, R.; TAYLOR, W. Compartments revealed in food-web structure. Nature, [S. l.], v. 426, p. 282-285, 2003. Doi: https://doi.org/10.1038/nature02115

LAKATOS, I. Falsification and the methodology of scientific research programs. In: LAKATOS, I.; MUSGRAVE, A. (ed.) Criticism and the growth of knowledge. Cambridge: Cambridge University Press, 1970. p. 91-195. [LAKATOS, I. O falseamento e a metodologia dos programas de pesquisa científica. In: LAKATOS, I.; MUSGRAVE, A. (org.) A crítica e o desenvolvimento do conhecimento. Tradução de Octavio Mendes Cajado. São Paulo: Cultrix; Editora da USP, 1979. p. 109-243.] https://doi.org/10.1017/cbo9781139171434.009

LAKATOS, I. History of science and its rational reconstructions. In: BUCK, C.; COHEN, R. (ed.) Boston studies in the philosophy of science.. Dordrecht: Reidel, 1971. v. 28, p. 91-135. https://doi.org/10.1007/978-94-010-3142-4_7

LITVIN, O.; CAUSTON, H.; CHEN, B.; PEER, D. Modularity and interactions in the genetics of gene expression. Proceedings of the National Academy of Science of the United States of America, v. 106, n. 16, p. 6441-6446, 2009. Doi: https://doi.org/10.1073/pnas.081020810

LORENZ, D.; JENG, A.; DEEN, M. The emergence of modularity in biological systems. Physics of Life Reviews, [S. I.], v. 8, n. 2, p. 129-160, 2011. Doi: https:// doi.org/10.1016/j.plrev.2011.02.003

MEURER, C. F. Sobre a viabilidade computacional de uma arquitetura cognitiva não-modular. Cognitio-Estudos, [S. I.], v. 14, n. 1, p. 55-73, 2017. Doi https:// doi.org/10.23925/1809-8428.2017v14i1p55-73

MONTOYA, J.; PIMM, S.; SOLÉ, R. Ecological networks and their fragility. Nature, [S. l.], v. 442, p. 259-264, 2006. Doi: https://doi.org/10.1038/nature04927

NEWELL, A. Unified theories of cognition. Cambridge, MA: Harvard University Press, 1990. 
NEYS, W. Automatic-heuristic and executive-analytic processing in reasoning: chronometric and dual task considerations. Quarterly Journal of Experimental Psychology, [S. l.], v. 59, n. 6, p. 1070-1100, 2006. Doi: http:// dx.doi.org/10.1080/02724980543000123

OATEN, M.; STEVENSON, R.; CASE, T. Disgust as a disease-avoidance mechanism. Psychological Bulletin, [S. l.], v. 135, n. 2, p. 303-321, 2009. Doi: http:// dx.doi.org/10.1037/a0014823

PAWLOWSKI, B.; DUNBAR, R. Impact of market value on human mate choice decisions. Proceedings of the Royal Society of London B, [S. l.], v. 266, n. 1416, p. 281-285, 1999. (1999a) Doi: https://dx.doi.org/10.1098/rspb.1999.0634

PAWLOWSKI, B.; DUNBAR, R. Withholding age as putative deception in mate search tactics. Evolution and Human Behavior, [S. l.], v. 20, n. 1, p. 53-69, 1999. (1999b) Doi: http://dx.doi.org/10.1016/S1090-5138(98)00038-5

PENTON-VOAK, I.; PERRETT, D. Female preference for male faces changes cyclically: further evidence. Evolution and Human Behavior, [S. l.], v. 21, n. 1, p. 39-49, 2000. Doi: http://dx.doi.org/10.1016/S1090-5138(99)00033-1

PINKER, S. How the mind works. London; New York: Penguin Books, 1997.

PUTNAM, H. The 'corroboration' of theories. In: SCHILPP, P. (ed.) The philosophy of Karl Popper. La Salle, IL: Open Court Publishing Co., 1974. p. 221-240.

REGNER, A. C. P. Feyerabend/Lakatos: adeus à razão ou construção de uma nova racionalidade? In: PORTOCARRERO, V. (org.) Filosofia, história e sociologia das ciências 1: abordagens contemporâneas. Rio de Janeiro: Editora Fiocruz, 1994. p. 103-131. Acessível em: http://books.scielo.org/id/rnn6q/ pdf/portocarrero-9788575414095-06.pdf

SAMUELS, R. Is the human mind massively modular? In: STAINTON, R. (ed.) Contemporary debates in cognitive science. New York: Blackwell, 2006. p. 37-56.

SCHLOSSER, G.; WAGNER, G. Modularity in development and evolution. Chicago: University of Chicago Press, 2004.

SHERLOCK, J.; ZIETSCH, B.; TYBUR, J.; JERN, P. The quantitative genetics of disgust sensibility. Emotion, [S. l.], v. 16, n. 1, p. 43-51, 2016. Doi: http://dx.doi. org/10.1037/emooo00101

SOHN, K. Men's revealed preference for their mates' ages. Evolution and Human Behavior, [S. l.], v. 38, n. 1, p. 58-62, 2017. Doi: http://dx.doi.org/10.1016/j.evolhumbehav.2016.06.007

SPERBER, D. Explaining culture. Oxford: Blackwell, 1996. 
SPIRIN, V.; GELFAND, M.; MIRONOV, A.; MIRNY, L. A metabolic network in the evolutionary context: multiscale structure and modularity. Proceedings of the National Academy of Science of the United States of America, v. 103, n. 23, p. 7500-7505, 2008. Doi: http://dx.doi.org/10.1073/pnas.0510258103

SUGIYAMA, L.; TOOBY, J.; COSMIDES, L. Cross-cultural evidence of cognitive adaptations for social exchange among the Shiwiar of Ecuadorian amazonia. Proceedings of the National Academy of Sciences, v. 99, n. 17, p. 11537-11542, 2002. Doi: http://dx.doi.org/10.1073/pnas.122352999

SYMONS, D. Beauty is in the adaptations of the beholder: the evolutionary psychology of the human female sexual attractiveness. In: ABRAMSON, P.; PINKERTON, S. (ed.) Sexual nature / sexual culture. Chicago: Chicago University Press, 1995. p. 80-118.

THIEFFRY, D.; SÁNCHEZ, L. Qualitative analysis of gene networks: toward the delineation of cross-regulatory modules. In: SCHLOSSER, G.; WAGNER, G. (ed.) Modularity in development and evolution. Chicago: University of Chicago Press, 2004. p. 222-243.

THORNTON, A.; CLAYTON, N.; GRODZINSKI, U. Animal minds: from computation to evolution. Philosophical Transactions of the Royal Society B, London, v. 367, n. 1603, p. 2670-2676, 2012. Doi: http://dx.doi.org/10.1098/rstb.2012.0270

TOOBY, J.; COSMIDES, L. On the universality of human nature and the uniqueness of the individual: the role of genetics and adaptation. Journal of Personality, [S. I.], v. 58, n. 1, p. 17-64, 1990. Doi: http://dx.doi.org/10.1111/j.1467-6494.1990.tboo907.x TOOBY, J.; COSMIDES, L. The psychological foundations of culture. In: BARKOW, J.; COSMIDES, L.; TOOBY, J. (ed.). The adapted mind: evolutionary psychology and the generation of culture. New York: Oxford University Press, 1992. p. 19-136. https://doi.org/10.1017/s0730938400018700

TYBUR, J.; INBAR, Y.; GULER, E.; MOLHO, C. Is the relationship between pathogen avoidance and ideological conservatism explained by sexual strategies? Evolution and Human Behavior, [S. l.], v. 36, n. 6, p. 489-497, 2015. Doi: http://dx.doi.org/10.1016/j.evolhumbehav.2015.01.006

TYBUR, J.; LIEBERMAN, D.; GRISKEVICIUS, V. Microbes, mating, and morality: individual differences in three functional domains of disgust. Journal of Personality and Social Psychology, [S. l.], v. 97, n. 1, p. 103-122, 2009. Doi: http://dx.doi.org/10.1037/ao015474 
TYBUR, J.; LIEBERMAN, D.; KURZBAN, R.; DESCIOLI, P. Disgust: evolved function and structure. Psychological Review, Washington, v. 120, n. 1, p. 6584, 2013. Doi: https://doi.org/10.1037/a0030778

VAN LIER, J.; REVLIN, R.; DE NEIS, W. Detecting cheaters without thinking: testing the automaticity of the cheater detection module. PlosOne, v. 8, n. 1, p. e53827. Doi: https://dx.doi.org/10.1371/journal.pone.0053827

WAGNER, G. Homologues, natural kinds and the evolution of modularity. American Zoology, v. 36, n. 1, p. 36-43, 1996. Doi: https://doi.org/10.1093/ icb/36.1.36

\section{Endereço Postal}

\section{César Fernando Meurer}

Universidade Federal de Uberlândia

Instituto de Filosofia

Avenida João Naves de Ávila, 2121

Bairro Santa Mônica

38408100 - Uberlândia, MG - Brasil. 